\title{
OKSIDENTALISME HASAN HANAFI
}

(Konstruk Epistemologi Pengembangan Studi Islam)

\section{Kamaruddin Mustamin}

IAIN Sultan Amai Gorontalo

Email: kamaruddin.mustamin@yahoo.com

\section{Abstract:}

Hasan Hanafi's Occidentalism hinted at an epistemological framework for the development of Islamic studies. The birth of identityism is based on his ideals to establish a shared position between Islam and the West in a constructiveproportional dialogue of knowledge. The three agendas offered in the form of our attitude towards old traditions, our attitude towards Western traditions, and our attitude towards reality, are an epistemological construct of the development of systemically intertwined Islamic studies. Our attitude towards the old tradition with its steps tries to provide innovation in Islamic studies which basically has a strong historical footprint, our attitude towards Western traditions tries to arouse Muslims' awareness that addressing the West must be more proportional in its historical framework, while our attitude towards reality directs Islamic studies as a study that is not separated from the reality that surrounds it.

Oksidentalisme Hasan Hanafi mengisyaratkan suatu kerangka epistemologi pengembangan studi Islam. Lahirnya oksidentalisme tersebut dilandasi oleh cita-cita beliau untuk membangun kesamaan posisi antara Islam dan Barat dalam suatu dialog pengetahuan yang konstruktif-proporsional. Tiga agenda yang ditawarkan berupa sikap kita terhadap tradisi lama, sikap kita terhadap tradisi Barat, serta sikap kita terhadap realita, merupakan suatu konstruk epistemologi pengembangan studi Islam yang terjalin secara sistemik. Sikap kita terhadap tradisi lama dengan langkah-langkahnya mencoba memberikan inovasi dalam studi Islam yang pada dasarnya memiliki jejak historis yang kuat, sikap kita terhadap tradisi Barat mencoba menggugah kesadaran umat 
52 Rausyan Fikr, Vol. 17 No. 1 Januari 2021: 51 - 73.

Islam bahwa menyikapi Barat harus lebih proporsional dalam kerangka historitasnya, sementara sikap kita terhadap realita mengarahkan studi Islam sebagai suatu kajian yang tidak terpisah dari realitas yang melingkupinya.

Kata Kunci Oksidentalisme, Hasan Hanafi, Epistemologi, Studi Islam

\section{PENDAHULUAN}

Dialog antara Islam dan Barat telah melewati perjalanan historis yang cukup panjang. Ketika Barat yang dalam hal ini adalah Eropa mengalami abad kegelapan yang ditandai dengam menguatnya otoritas gereja dalam berbagai aspek kehidupan termasuk pengembangan ilmu pengetahuan, beberapa tokoh Islam seperti Ibnu Rusyd, al-Kindi, dan yang lainnya mampu hadir sebagai jembatan yang kemudian mengantarkan Eropa keluar dari abad kegelapan tersebut melalui sebuah gerakan kebangkitan yang disebut renaissance. Dalam perkembangannya, relasi antara Islam dan Barat juga diwarnai dengan berbagai macam konflik yang salah satu bukti monumentalnya adalah terjadinya perang Salib yang berlangsung dalam waktu yang lama.

Menguatnya konflik yang terjadi antara Islam dan Barat telah berimplikasi pada berbagai sektor kehidupan manusia mulai dari ekonomi, politik, sosial budaya, sampai pada transformasi ilmu pengetahuan. Dalam perkembangannya, posisi Islam yang banyak memberikan kontrubusi bagi Barat untuk mendapatkan era pencerahan (aufklarung) seperti mengalami kemuduran sehingga yang terjadi saat ini Barat yang justru mengambil alih peran sebagai kiblat berbagai aspek strategis dalam kehidupan manusia. Fenomena ini digambarkan oleh M. Rusydi bahwa kajian akademis yang ada dalam tradisi keserjanaan Barat selama ini cenderung mengisolasi sisi historis dari Islam sebagai sebuah agama yang telah banyak memberikan kontribusi dalam perkembangan ilmu 
pengetahuan termasuk pada Barat sekalipun. Yang ada selama ini adalah mereka memposisikan Islam sekedar sebagai agama dan belum menyentuh ranah peradabannya. Parahnya, kajian Islam di Barat cenderung terjebak pada kepentingan ideologis Barat yang profan. ${ }^{1}$ Yang menarik kemudian untuk dicermati adalah ketika Barat semakin agresif dalam menguatkan posisinya sebagai kiblat ilmu pengetahuan dengan kajian orientalismenya yang mengarah pada Islam sebagai salah satu obyek kajiannya. Upaya Barat ini semakin menemukan momentum ketika kajian orientalisme yang dikembangkannya dianggap berhasil melahirkan berbagai pendekatan alternatif yang baru dalam studi Islam. Hal ini pula yang kemudian semakin mengukuhkan posisi Barat sebagai kiblat ilmu pengetahuan yang dipuja-puja oleh berbagai pihak termasuk di kalangan umat Islam sendiri.

Pada dasarnya tidak ada yang salah ketika berbagai pendekatan dalam studi Islam yang ditemukan Barat tersebut muncul sebagai pendekatan alternatif yang diharapkan bisa memberikan hasil kajian yang lebih holistik dan komprehensif, yang salah kemudian adalah ketika ketertarikan terhadap hasil kajian orientalisme tersebut berupa pendekatan alternatif pendekatan dalam studi Islam justru semakin menjauhkan umat Islam dari khazanah keilmuan Islam itu sendiri. Konsekuensinya, umat Islam menjadi pihak yang epistemologi keilmuannya harus terkonfirmasi pada epistemologi keilmuan Barat untuk bisa dikatakan sebagai sesuatu yang benar. Fenomena eurosentrisme ini kemudian menggugah ilmuwan Muslim untuk mengembalikan marwah studi Islam yang salah satunya adalah Hasan Hanafi dengan konsep oksidentalismenya. Kerangka epistemologis yang dijadikan sebagai basis dalam pengembangan studi Islam dengan konsep oksidentalismenya menunjukkan perhatian yang besar dari

${ }^{1}$ M. Rusydi, "Dinamika Studi Islam di Barat", Jurnal Studia Insania, Vol. 4 No. 1 Tahun 2016, h. 57 
54 Rausyan Fikr, Vol. 17 No. 1 Januari 2021: 51 - 73.

Hasan Hanafi terhadap epistemologi sehingga dalam salah satu pernyataannya dia menyatakan bahwa penguasaan epistemologi yang baik berimplikasi praktis pada progresivitas pengetahuan, sebailknya minimnya penguasaan epistemologi berimplikasi praktis pada terhambatnya pengembangan pengetahuan. ${ }^{2}$

Sebagai suatu kerangka dialog antara Islam dengan Barat dalam transformasi ilmu pengetahuan, oksidentalisme Hasan Hanafi telah menjadi suatu pembahasan tersendiri dalam perkembangan ilmu pengetahuan dengan segala dinamika pengembangannya. Sejumlah artikel telah mengaji pemikiran Hasan Hanafi, ${ }^{3}$ namun artikel fokus untuk mengelaborasi konsep oksidentalisme Hasan Hanafi sebagai konstruk epistemologi pengembangan studi Islam. Metode analisis yang digunakan adalah analisis wacana terhadap pemikiran Hasan Hanafi dalam karyanya dengan pendekatan hermeneutik. Namun sebelum menganalisa konsep oksidentalimse Hasan Hanafi, penulis menjelaskan biografi intelektualnya.

\section{HASAN HANAFI DAN BIOGRAFI INTELEKTUALNYA}

Hasan Hanafi merupakan tokoh pemikir Muslim kontemporer berdarah Maroko yang lahir d Kairo Mesir tepatnya pada 13 Pebruari 1935. ${ }^{4}$ Pendidikan dasarnya diselesaikan pada tahun 1948 dimana pada proses menempuh pendidikan tersebut dia juga telah mendalam Alquran di bawah bimbingan Syekh Sayyid. Tidak heran kemudian apabila dalam usia lima tahun, Hasan Hanafi telah mampu menghafal Alquran. Setelah menyelesaikan

\footnotetext{
${ }^{2}$ Hasan Hanafi, Dirasat Falsafiyah, (Kairo: Maktabah al-Misriyah, tt.), h. 261

3 Muhammad Patri Arifin, "Hermeneutika Fenomenologis Hasan Hanafi”, Rausyan Fikr: Jurnal Studi Ilmu Ushuluddin dan Filsafat, Vol. 13 No.1, 2017, 1-26.

${ }^{4}$ John L. Esposito, The Oxford Encyklopedia of the Modern Islamic World, (New York: Oxford University Press, 1995), h. 98
} 
pendidikan dasarnya, Hasan Hanafi kemudian melanjutkan pendidikan pada Madrasah Tsanawiyah Khalil Agha Kairo dan diselesaikan pada 1952. Dalam proses pendidikannya selama di Madrasah Tsanawiyah Khalil Agha tersebut, berbagai kajian keislaman yang diselenggarakan oleh kelompok Ikhwanul Muslimin aktif diikuti sehingga hal tersebut membentuk kesadaran intelektualnya terkait dengan Islam dan berbagai ideologi pergerakan yang mendasarinya. Hanafi memperoleh gelar sarjana mudanya dari Universitas Kairo, Jurusan Filsafat Fakultas Adab tahun 1956. Kemudian ia melanjutkan ke Universitas Sorbone Perancis dengan konsentrasi kajian pemikiran Barat modern dan pra-modern tepatnya pada tahun $1966 .{ }^{5}$ Pendidikannya di Perancis tersebut diselesaikan pada dua jenjang pendidikan yang dalam hal ini adalah magister dan doktor. Selama di Perancis, Hasan Hanafi mendalami berbagai disiplin ilmu termasuk yang berkaitan erat dengan metode berfikir, mulai dari pemikiran fenomenologi Husserl (1859-1938) yang mengakui kebenaran empiris, kebenaran teoritis (akal) dan kebenaran nilai. Kemudian ia juga mendalami pemikiran pembaruan dan sejarah filsafat Jean Guitton (19011999), sampai analisis kesadaran Paul Ricouer (1913-2005), pemikiran Louis Massignon (1883-1962) dalam bidang logika pembaruan. ${ }^{6}$ Berbagai metode berpikir tersebut kemudian membentuk potensi intelektualnya dalam memahami berbaga fenomena sosial yang ada pada zamannya termasuk relasi antara Islam dan Barat.

Sebagai seorang tokoh tokoh Muslim yang sangat produktif dalam mengemukakan berbagai gagasan konstruktif dalam

\footnotetext{
${ }^{5}$ Riza Zahriyal Falah dan Irzum Farihah, Pemikiran Teologi Hassan Hanafi, (Jurnal Fikrah: Jurnal Ilmu Aqidah dan Studi Keagamaan Vol. 3 No. 1 Tahun 2015), h. 203-204

${ }^{6}$ A. Khudori Sholeh, Filsafat Islam, (Sleman: Ar-Ruzz Media, 20014), h. 65
} 
pengembangan studi Islam yang termasuk disertasi setebal 900 halaman yang tulis dalam penyelesaian doktornya pada Universitas Sorbone Perancis dan kemudian dikatakan sebagai karya tulis terbaik di Mesir pada tahun 1971 dengan judul "Essai Sur la Methode D'exegese". Di samping disertasi tersebut, Hasan Hanafi telah mengemukakan banyak karya tulis yang diantaranya adalah, 1) Les Méthodes D'exégese: Essai Sur la Science des Fondements de la Compréhension "Ilm Ușul al-Fiqh" (1965), al-Turats wa alTajdid (1980), L'exégese de la Phénoménologie: Létat Actuelle de la Méthode Phénoménologique et Son Application au Phénomene Religieux (1981), al-Yasar al-Islāmì: Kitābat fi an-Nahdhah alIslämiyyah (1980), La Phénoménologie de Lexégese: Essai D'une Herméneutique Existentielle a Partir du Nouveau Testament (1988), Oksidentalisme: Sikap Kita Terhadap Tradisi Barat (2000), Islam in the Modern World: Tradition, Revolution and Culture (2000), Oposisi Pasca Tradisi (2003), Cultures and Civilizations: Cultural Creativity and Religious Dialogue (2007), Cultures and Civilizations: The Meridian Thought (2007), dan yang lainnya. ${ }^{7}$ Dalam pengembangan keilmuannya, di samping menjadi dosen tetap pada Universitas Kairo Mesir, Hasan Hanafi juga aktif mengajar pada beberapa universitas terkenal dari berbagai negara di luar Mesir seperti Perancis, Belgia, Amerika Serikat, Kuwait, Maroko, dan Tokyo.

\section{OKSIDENTALISME HASAN HANAFI: KONSEP DAN APLIKASI}

Kelahiran Oksidentalisme Hasan Hanafi bukan merupakan suatu konsep yang tidak memiliki akar historis yang melatarbelakangi kelahirannya. Menyikapi hal tersebut, George

\footnotetext{
${ }^{7}$ Abdurrahman Kasdi dan Umma Farida, Oksidentalisme sebagai Pilar Pembaharuan: Telaah terhadap Pemikiran Hasan Hanafi, (Jurnal Fikrah Vol. 1 No. 2 Tahun 2013), h. 237
} 
Lenczowski mengemukakan bahwa kelahiran Hasan Hanafi disambut dengan pergolakan sosial politik yang cukup mempengaruhi kondisi berbagai aspek kehidupan saat itu. Pergolakan sosial politik tersebut adalah adanya dua kelompok dari dua kutub ideologi berbeda yang saling berebut pengaruh satu sama lain yaitu partai komunis yang semakin kuat atas pengaruh Uni Soviet di seluruh dunia serta kelompok Ikhwanul Muslimin yang memiliki karakteristik gerakan yang anti Barat. ${ }^{8}$

Istilah "oksidentalisme" dalam bahasa Arab dikenal dengan istilah "al-istighrab". Dalam memberikan kerangka etimologis dan terminologis terkait oksidentalisme, Anwar Sadat mengemukakan bahwa istilah tersebut berasal dari kata "oksiden" yang dapat diartikan dengan Barat. Adapun kata "oksidental" merupakan bentuk kata sifat yang merujuk pada segaa sesuatu yang bersifat kebarat-baratan dalam berbagai dimensi kehidupan manusia seperti pada dimensi ideology, budaya, pemikiran ataupun praktik. Oleh karena itu, oksidentalisme dapat dipahami sebagai kajian ilmu yang mempelajari aspek sosial yang berhubungan dengan Barat berikut peradabannya secara holistik dan komprehensif. ${ }^{9}$ Apabila ingin dirujuk pada fakta empirik-historisnya, kemunculan oksidentaalisme memiliki relevansi konstruktif dengan konsep “orientalisme" yang justru sebaliknya menjadi berbagai aspek yang ada di Timur sebagai obyek kajiannya.

Hadirnya oksidentalisme sebagai suatu konsep berpikir dan bertindak dalam menyikapi relasi Islam dengan Barat tidak trelepas dari berbagai tujuan yang ditegaskan oleh Hasan Hanafi sebagai berikut:

\footnotetext{
${ }^{8}$ George Lenczowski, Timur Tengah di Tengah Kancah Dunia, terj. Asgar Bixby, (Bandung: Sinar Baru, 1992), h. 298

${ }^{9}$ Anwar Sadat, Oksidentalisme: Menuju Integrasi Epistemologi Studi Islam, (Jurnal Tajdid: Jurnal Pemikiran Keislaman dan Kemanusiaan Vol. 1 No.1 Tahun 2017), h. 137
} 
58 Rausyan Fikr, Vol. 17 No. 1 Januari 2021: 51 - 73.

1. Kontrol atau pembendungan atas kesadaran Eropa dari awal sampai akhir, sejak kelahiran hingga keterbentukannya.

2. Mempelajari kesadaran Eropa dalam kapasitas sebagai sejarah bukan sebagai kesadaran yang berada di luar sejarah

3. Mengembalikan Barat ke batas alamiahnya, mengakhiri perang kebudayaan, menghentikan ekspansi tanpa batas, mengembalikan filsafat Eropa ke lingkungan di mana ia dilahirkan, sehingga partikulasi Barat akan terlihat.

4. Menghapus mitos "kebudayaan kosmopolit" dengan melakukan langkah-langkah, a) menemukan spesifikasi bangsa di seluruh dunia, dan bahwa setiap bangsa memiliki tipe peradaban serta kesadaran sendiri, bahwa ilmu fisika dan teknologi tersendiri seperti yang terjadi di India, Cina, Afrika dan Amerika Latin, b) serta menerapkan metode sosiologi ilmu pengetahuan dan antropologi peradaban pada kesadaran Eropa yang selama ini diterapkan produsennya pada kesadaran non Eropa.

5. Membuka jalan bagi terciptanya inovasi bangsa non Eropa dan membebaskannya dari "akal" Eropa yang menghalangi nuraninya, sehingga bangsa non Eropa dapat berpikir dengan "akal" dan kerangka lokalnya sendiri.

6. Menghapus rasa rendah diri yang terjadi pada bangsa non Eropa ketika berhadapan dengan bangsa Eropa dan memacu mereka menuju tahap inovator setelah sebelumnya hanya berperan sebagai konsumen kebudayaan, ilmu pengetahuan dan kesenian.

7. Melakukan penulisan ulang sejarah agar semaksimal mungkin dapat mewujudkan persamaan bagi seluruh bangsa di dunia yang sebelumnya menjadi korban perampas kebudayaan yang dilakukan bangsa Eropa.

8. Permulaan filsafat baru yang dimulai dari angin Timur. Hal ini sesuai dengan ditemukannya siklus peradaban dan 
hukum evolusinya yang lebih komprehensif dan universal dibanding yang ada di lingkungan Eropa, dan tinjuan ulang terhadap posisi bangsa Timur sebagai permulaan sejarah seperti dikatakan Herder, Kant, dan Hegel.

9. Mengakhiri orientalisme dengan mengubah Timur dari obyek menjadi subyek dan meluruskan hukum-hukum yang diterapkan Barat ketika berada di puncak kebangunanya kepada peradaban Timur yang sedang berada dalam keterlelapan tidur dan kealpaannya.

10. Menciptakan oksidentalisme sebagai ilmu pengetahuan yang akurat karena fondasi dan gejala oksidentalisme pada hakikatnya telah ada dalam generasi kita tapi belum mampu menghasilkan sebuah disiplin ilmu.

11. Membentuk peneliti-peneliti tanah air yang mempelajari peradabannya dari kacamata sendiri dan mengkaji peradaban lain secara netral dari kajian yang pernah dilakukan Barat terhadap peradaban lain.

12. Dimulainya generasi pemikir baru yang dapat disebut sebagai filosof, pasca generasi pelopor di era kebangkitan. Hal ini dimaksudkan untuk menjawab pertanyaan yang sering meluncur seputar, apakah kita memiliki filosuf?

13. Membebaskan ego dari kekuasaan the other pada tingkat peradaban agar ego dapat memposisikan diri sebagai dirinya sendiri.

14. Tujuan terakhir, adalah dengan Oksidentalisme manusia akan mengalami era baru di mana tidak ada lagi penyakit rasialisme terpendam seperti yang terjadi selama pembentukan kesadaran Eropa yang akhirnya menjadi bagian dari strukturnya. ${ }^{10}$

${ }^{10}$ Hasan Hanafi, Oksidentalisme: Sikap Kita terhadap Tradisi Barat, Terj. M. Najib Buchori, (Jakarta: Paramadina, 2000), h. 51-58, Yolies Yongki 
Dengan merujuk pada berbagai tujuan di atas, terlihat bagaimana oksidentalisme Hasan Hanafi dengan beberapa tujuan yan terikat secara sistemik dalam penerapannya. Tentu saja apa yang dilakukan oleh Hasan Hanafi dengan konsep oksidentalismenya tidak muncul begitu saja. Berbagai fakta empirik telah mendorong Hasan Hanafi untuk mengembangkan konsep oksidentalisme tersebut sebagai antitesa atas tesa untuk selanjutnya bermetamorfosis sebagai sintesa. Hal ini sesuai dengan scientific revolution Thomas Kuhn yang menyatakan bahwa terbentuknya suatu pengetahuan terbentuk dari relasi konstruktifevolutif antara tesa, antitesa dan sintesa. Dalam kaitannya dengan oksidentalisme Hasan Hanafi, beberapa tesa (fakta empiris) yang kemudian disikapi dengan antitesa (sikap responsif) untuk selanjutnya berujung pada sintesa (oksidentalisme) dikemukakan oleh Moh. Nurhakim sebagai berikut, 1) keberhasilan Barat dalam bidang sains dan teknologi pada era modern melahirkan superioritas Barat terhadap yang lain mereka yang ada di luar Barat (the other), 2) invasi peradaban Barat ke dalam negeri-negeri Timur baik secara pasif maupun dominan memaksa perubahan pola pikir dan sikap kebarat-baratan bangsa Timur sehingga terjadi westernisasi, 3) munculnya gejala westernisasi mengakibatkan juga lahirnya gejala fundamenlisme dan revivalisme yang berlebihlebihan di kalangan bangsa Timur termasuk di dalamnya adalah kaum muslim, 4) pada tataran keilmuan, pola kajian yang dilakukan oleh para orientaslis terhadap Timur dilakukan secara subyektif sehingga sterotip yang buruk terhadap Timur, termasuk dunia Islam, semakin besar. Di samping itu, sikap yang merendahkan itu sudah bersikap retorik apologetik dan emosional, 5) dibutuhkan kajian-kajian ilmiah untuk dijadikan sebagai pijakan

Nata, Oksidentalisme, (JAU: Jurnal Penelitian dan Pemikiran Islam Vol. 2 No.1 Tahun 2015), h. 121-124 
bangsa Timur untuk melepaskan diri dari ketergantungan dan dominasi bangsa Barat. ${ }^{11}$

Dalam aplikasinya, oksidentalisme Hasan Hanafi merupakan agenda kedua dari proyek "Tradisi dan Pembaharuan" yang digagasnya dimana dipahami bahwa ketiga agenda tersebut meliputi, 1) sikap kita terhadap tradisi lama, 2) sikap kita terhadap tradisi Barat, 3) serta sikap kita terhadap realitas. ${ }^{12}$ Ketiga egenda tersebut pada dasarnya mengarahkan bagaimana umat Islam yang selama ini sudah terhipnotis dalam daya magis Barat dakam berbaga dimensi kehidupan untuk merekonstruksi ulang relasi antara Islam dan Barat yang lebih proporsional.

\section{STUDI ISLAM: JEJAK PERGUMULAN ISLAM DAN BARAT}

Studi Islam dalam sejarah pergumulan Islam dan Barat tidak bisa dipisahkan dari berbagai kerangka historis yang melatarbelakanginya. Perebutan superioritas di antara keduanya adalah fenomena yang banyak mewarnai relasi keduanya. Dalam perkembangan awalnya, orientalisme yang banyak dilakukan oleh intelektual Barat memiliki tujuan-tujuan pragmatis seperti kolonialisme, misionarisme, dan semacamnya. Konsekuensinya, studi Islam dalam bingkai orientalisme tersebut berupaya untuk mencari berbagai kelemahan yang ada dalam Islam, yang menjadi salah satu simbol peradaban Timur saat itu, untuk kepentingan ekspansi wilayah kekuasaan ataupun untuk penyebaran agama Kristen yang pada saat itu kadang-kadang dilakukan secara bersamaan dan hal yang sama juga terjadi pada saat Islam melakukan ekspansi wilayah maka dalam proses tersebut juga ada proses penyebaran agama Islam.

${ }^{11}$ Moh. Nurhakim, Islam, Tradisi \& Reformasi: "Pragmatism" Agama dalam PemikiranHasan Hanafi, (Yogyakarta: Bayumedia Publishing dan UMM Press, 2003), h. 87-88

${ }^{12}$ Hasan Hanafi, Oksidentalisme: Sikap Kita terhadap Tradisi Barat, h. 5 
Seiring dengan perkembangan selanjutnya, studi Islam yang dilakukan oleh para intelektual Barat sudah mengalami transformasi dari yang tadinya bersifat pragmatis menjadi akademis sehingga obyektivitas kajian lebih tampak. Dari fenomena tersebut, dapat dipahami bahwa ada semacam hubungan simbiosis mutualisme yang mewarnai relasi antara Islam dan Barat sehingga meskipun pada satu sisi hubungan keduanya kadangkadang terjadi dalam pusaran konflik yang berkepanjangan tapi hal tersebut tidak bisa menutupi fakta historis bahwa konflik tersebut pada sisi yang lain juga mendorong terjadinya transformasi ilmu pengetahuan yang masif di antara keduanya. Tidak salah apabila salah seorang ilmuwan Barat yang bernama Montgomery Watt dengan obyektifitas keilmuwannya, dan dikutip Faisal Ismail, mengemukakan bahwa:

For our cultural indebtedness to Islam, we Europeans have a blind spot. We sometimes belittle the extent and importance of Islamic influence in our heritage, and sometimes overlook it altogether. For the sake of good relation with Arabs and Muslims we must acknowledge our indebtedness to the full. To try to cover it over and deny it is a mark of false pride. (Terkait hutang budi kebudayaan kita kepada Islam, kita orang-orang Eropa mempunyai cara pandang yang buta. Kadang-kadang kita meremehkan arti penting luasnya pengaruh Islam dalam warisan budaya kita, dan kadang-kadang pula kita tidak mengacuhkannya. Demi kepentingan hubungan baik kita dengan bangsa-bangsa Arab dan umat Islam, kita harus mengakui sepenuhnya hutang budi kita kepada mereka. Mencoba menutupi dan menyangkal pengaruh ini adalah pertanda kebanggaan yang palsu saja). ${ }^{13}$

13 Faisal Ismail, Kontribusi Islam terhadap Eropa pada Abad Pertengahan, https://rumahkitab.com/kontribusi-islam-terhadap-eropa-padaabad-pertengahan/ (15 April 2020) 
Menyikapi hal tersebut, Carl W. Ernst dan Richard C. Martins mengemukakan beberapa alasan utama yang mendorong studi Islam menunjukkan grafik peningkatan yang cukup signifikan di dunia Barat yang dalam hal ini adalah, 1) munculnya ketidakpusan dari berbagai pihak baik dari ilmuwan Muslim ataupun Islamisis yang berasal dari non-muslim yang melihat bahwa studi Islam yang ada selama ini cenderung dianggap menafikan berbagai sisi obyektifitas kajian Islam, 2) munculnya pemikir-pemikir studi Islam dan sejarah sejarahnya seperti Charles J. Adam, Montgomery Watt, Wilfred Cantwell Smith, dan yang lainnya dengan karya-karya monumental yang menginspirasi studi Islam lebih holistik dan komprehensif 3) serta adanya kesadaran dan upaya untuk menciptakan suatu kajian Islam yang lebih adil dan obyektif. ${ }^{14}$

Adanya peningkatan studi Islam di Barat tersebut, pada dasarnya, telah ada dari dulu hanya saja yang terjadi kemudian adalah adanya pergeseran paradigma studi Islam yang tadinya berorientasi penjajahan menjadi berorientasi akademik sebagaiman telah disebutkan sebelumnya. Hal ini tentu saja menggeser epistemologi penerapannya yang tadinya dilakukan dalam bingkai subyektivitas yang pragmatis untuk selanjutnya dilaksanakan secara obyektif. Dengan adanya pergeseran paradigma tersebut, tidak mengherankan apabila dalam menyikapi kajian ketimuran yng dilakukan oleh para orientalis memunculkan respon yang berbeda sebagaimana dikemukakan oleh Nurcholis Madjid bahwa di kalangan intelektual Muslim ada yang menilai bahwa orientalis

${ }^{14}$ Carl W. Ernst dan Richard C. Martin, Introduction: Toward a PostOrientalist Approach, (Columbia : University of South Carolina Press, 2010), h. 6-7 


\section{Rausyan Fikr, Vol. 17 No. 1 Januari 2021: 51 - 73.}

tersebut memberikan dampak yang positif bagi studi Islam dan ada yang menilai bahwa mereka memberikan dampak negatif. ${ }^{15}$

Dalam perkembangannya, studi Islam telah menjadi salah satu alternatif kajian ilmu pengetahuan yang dibuka pada beberapa perguruan tinggi terkenal di Barat seperti yang ada di Universitas McGill Kanada, Universitas Leiden Belanda, Universitas Bonn Jerman, Universitas George Washington di Amerika Serikat, Universitas Durham di Inggris dan yang lainnya. Tidak mengherankan kemudian apabila dari Barat muncul berbagai pendekatan alternatif dalam studi Islam seperti Dekonstruksi yang digagas Jacques Derrida, Hermeneutika yang digagas oleh HansGeorg Gadamer, Arkeologi Pengetahuan yang digagas Michael Foucault, dan yang lainnya.

\section{OKSIDENTALISME DAN KONSTRUK EPISTEMOLOGI PEMIKIRAN ISLAM HASAN HANAFI}

Studi Islam merupakan suatu kerangka kajian yang mengarah pada Islam sebagai kerangka teologis-normatif dan penerapannya dalam kehidupan manusia. Merujuk pada kerangka kerja oksidentalisme yang ditawarkan Hasan Hanafi, terlihat bahwa tiga agenda yang diajukan dalam proyek "Tradisi dan Pembaharuan" yang dalam hal ini adalah 1) sikap kita terhadap tradisi lama, 2) sikap kita terhadap tradisi Barat, 3) serta sikap kita terhadap realitas, ${ }^{16}$ telah memberikan suatu kerangka epistemologis dari konstruk epistemologi pengembangan studi Islam. Sebagaimana dipahami bahwa epistemologi merupakan kerangka filsafat yang berbicara tentang apa yang memungkinkan untuk diketahui dari pengetahuan dan bagaimana cara

\footnotetext{
15 Nurcholis Madjid, Kaki Langit Peradaban Islam, (Jakarta: Paramadina, 1997), h. 59.

${ }^{16}$ Hasan Hanafi, Oksidentalisme: Sikap Kita terhadap Tradisi Barat, h. 5
} 
memperolehnya. ${ }^{17}$ Hal senada juga dikemukakan oleh M. Amin Abdullah bahwa epistemologi merupakan kerangka filsafat mencoba untuk menjawab beberapa pertanyaan seperti, apa itu pengetahuan?, bagaimana cara memperoleh pengetahuan?, metode apa yang dapat digunakan dalam mendapatkan pengetahuan?, serta apakah pengalaman dan akal pikiran mampu memahami struktur fundamental dari realitas? ${ }^{18}$ Secara umum bisa dikatakan bahwa epistemologi pengembangan studi Islam dapat dipahami sebagai suatu upaya untuk mengkonstruk pengembangan studi Islam itu sendiri dengan melihat bagaimana peluang pengembangan studi Islam dan strategi dalam pengembangannya.

Dalam kaitannya dengan posisi oksidentalisme sebagai agenda kedua dari proyek "Tradisi dan Pembaharuan" yang dalam hal ini adalah "sikap kita terhadap tradisi Barat, Hasan Hanafi ingin menggugah kesadaran umat Islam bahwa peradaban Barat yang selama ini mendikte kesadaran intelektual umat Islam telah membentuk superioritas Barat atas Islam dalam bingkai vertikalkordinatif. Dalam proses tersebut, apa yang datang dari Barat selalu dianggap sebagai sesuatu yang paling benar karena dalam kepercayaan mereka yang di Timur yang merupakan umat Islam Barat denan segala perkembangannya merupakan standar kebenaran itu sendiri. Konsekuensinya, segala sesuatu yang sesuai dengan Barat diterima sebagai suatu kebenaran sebaliknya segala sesuatu yang berbeda dengan Barat dianggap sebagai suatu hal yang memiliki memiliki kekurangan dalam lokus standar kebenaran yang diciptakan oleh Barat. Dalam proses tersebut, posisi umat Islam persis seperti pemain drama yang pentas dalam panggung peradaban dimana yang menajdi sutradaranya adalah Barat itu

${ }^{17}$ Mohammad Adib, Filsafat Ilmu: Ontologi, Epistemologi, Aksiologi, dan Logika Ilmu Pengetahuan, (Yogyakarta: Pustaka Pelajar, 2010), h. 74

${ }^{18}$ M. Amin Abdullah, Islamic Studies di Perguruan Tinggi: Pendekatan Integratif-Interkonektif, (Yogyakarta: Pustaka Pelajar, 2006), h. 117 
sendiri. Upaya yang dilakukan oleh Hasan Hanafi dalam kaitannya dengan bagaimana seharusnya sikap kita sebagai umat Islam terhadap Barat adalah perlunya memperkuat umat Islam dari dalam dari tradisinya sendiri termasuk dalam konteks ini adalah tradisi keilmuan yang ada dalam Islam.

Ketika epistemologi sebagai teori pengetahuan mempertanyakan apa itu pengetahuan maka dalam konteks konstruk epistemologi pengembangan studi Islam dalam lokus oksidentalisme Hasan Hanafi bisa dipahami sebagai format ideal yang memungkinkan untuk dicapai dalam pengembangan studi Islam. Pembahasan tentang konsep ideal yang digagas dalam oksidentaisme Hasan Hanafi tersebut mengingatkan pada upaya Emile Durkheim dalam memperkenalkan fungsi agama secara sosial. Dalam upaya tersebut Emile Durkheim memperkenalkan fungsi sosial agama terdiri atas fungsi kontrol sosial, fungsi solidaritas sosial, fungsi pemberian arti hidup, fungsi perubahan sosial, serta fungsi dukungan psikologis. ${ }^{19}$ Fungsi sosial agama ini selaras dengan konsep ideal studi Islam yang digagas dalam oksientalisme Hasan Hanafi. Fungsi kontrol sosial misalnya, Hasan Hanafi melihat bahwa sudah sepantasnya umat Islam membangun suatu langka terstruktur dalam menciptakan kontrol sosial yang lebih adil dalam memahami relasi antara ego dan the other, antara umat Islam dan Barat. Hal ini bisa dilihat dari pernyataan Hasan Hanafi sebagai berikut:

Kalaupun generasi kita telah merampungkan tugas pembebasan dari penjajah, pendudukan militer, kemudian mengubah revolusi menjadi sebuah negara yang mewujudkan kemerdekaan ekonomi, maka tugas itu belumlah sempurna. Di antara kita ada yang berupaya memperoleh kemerdekaan tidak hanya dari penjajahan

${ }^{19}$ Steven Lukes, Emile Durkheim: His Life and Work, (London: Pinguin Book, 1992), h. 9-13 
militer dan ekonomi, tetapi juga dari penjajahan kebudayaan dan ilmu pengetahuan. Jalan yang harus kita tempuh masih panjang meskipun sudah banyak orang mebicarakan tentang perang kebudayaan dan alih ilmu pengetahuan. ${ }^{20}$

Apa yang dikemukakan Hasan Hanafi tersebut menunjukan konsep ideal studi Islam yang tidak kehilangan jati diri ketika berhadapan dengan berbagai pengaruh dari luar yang disebutnya sebagai kemerdekaan dalam bentuk lain dari sekedar kemerdekaan atas penjajahan militer. Studi Islam, menurutnya, merupakan suatu kajian pengetahuan yang memiliki akar tradisi yang kuat. Tidak salah apabila kemudian Hasan Hanafi mendahului agenda kedua dari proyek "Tradisi dan Pembaharuan" yang digagasnya yang dalam hal ini adalah "sikap kita terhadap tradisi Barat" dengan "sikap kita terhadap tradisi lama". Konstruk epistemologi pengembangan studi Islam yang digagasnya melihat bahwa konsep ideal pengembangan studi Islam yang memungkinkan untuk dicapai adalah adanya kemandirian identitas dari studi Islam dalam menghadapi transformasi ilmu pengetahuan. Bagi Hasan Hanafi, pertemuan studi Islam dengan berbagai studi di luar studi Islam yang memiliki kerangka epistemologi yang berbeda merupakan suatu fenomena transformasi ilmu pengetahuan yang tidak bisa dihindari tapi studi Islam dalam proses tersebut harus tetap mampu mempertahankan identitasnya. Identitas kerangka epistemologi studi Islam tersebut telah digambarkan oleh Mujamil Qamar bahwa epistemologi keilmuan Barat bersifat skeptis, rasional-empiris, dikotomik, positif-obyektif, dan anti-metafisika. ${ }^{21}$ Sebagai antitesanya, epistemologi keilmuan Islam lahir dalam memberikan corak transformasi ilmu pengetahuan dengan karakternya yaitu

${ }^{20}$ Hasan Hanafi, Oksidentalisme: Sikap Kita terhadap Tradisi Barat, h. 58

${ }^{21}$ Mujamil Qomar, Epistemologi Pendidikan Islam: Dari Metode Rasional Hingga Metode Kritik, (Jakarta: Penerbit Erlangga, 2005), h. 58-86. 
bersandar pada kekuatan spiritual, adanya hubungan yang harmonis antara wahyu dan akal, interdepensi akal dengan intuisi, berorientasi teosentris, dan terikat nilai. ${ }^{22}$ Dengan "sikap kita terhadap tradisi lama", studi Islam tidak kehilangan identitasnya karena para ilmuwan Muslim sejak dulu telah meletakkan suatu kerangka pengembangan studi Islam yang berbasis pada nilai-nilai normativitas Islam.

Dalam kaitannya dengan metode yang dapat diterapkan dalam mewujudkan pengembangan studi Islam tersebut, konstruk epistemologi keilmuan pengembangan studi Islam dalam lokus oksidentalisme Hasan Hanafi mengisyaratkan bahwa adopsi berbagai pendekatan studi Islam yang ada di luar Islam, khususnya Barat, merupakan suatu keniscayaan. Pergumulan Islam dan Barat dalam jejak historitas keduanya merupakan suatu fakta sejarah yang tidak terbantahkan, baik yang sifatnya konstruktif ataupun destruktif. Dalam hal metode yang digunakan untuk mewujudkan hal tersebut, Hasan Hanafi telah memberikan flatform bagaimana kita menjadikan oksidentalisme sebagai sebagai suatu konstruk pengembangan studi Islam yang kuat secara epistemologis sekaligus menjadikan studi Islam memiliki identitas diri dalam spektrum eurosentrisme dan westernisasi. Hal ini terlihat pada tujuh langkah yang terkandung pada agenda pertama dari proyek "Tradisi dan Pembaharuan" yang terdiri atas, 1) dari teologi ke revolusi, 2) dari transferensi ke inovasi, 3) dari teks ke realita, 4) dari kefanaan menuju keabadian, 5) dari teks ke rasio, 6) akal dan alam, 7) serta manusia dan sejarah. ${ }^{23}$ Ketujuh langkah yang ditawarkan Hasan Hanafi tersebut dapat menguatkan konstruk

${ }^{22}$ Mujamil Qomar, Epistemologi Pendidikan Islam: Dari Metode Rasional Hingga Metode Kritik, h. 125-159.

${ }^{23}$ Hasan Hanafi, Oksidentalisme: Sikap Kita terhadap Tradisi Barat, h. 3 
epistemologi pengembangan studi Islam dalam kerangka metodologisnya. Dari teologi ke revolusi misalnya, yerlihat ada upaya daru Hasan Hanafi untuk mengarahkan sikap dan tindakan umat Islam dalam memahami tradisi lama, termasuk studi Islam, bukan hanya pada batas-batas teologisnya yang bersifat normatif tapi kurang menyentuh sisi historitasnya. Pemahaman umat Islam terhadap tradisi tidak boleh menjebak mereka menjadi orang-orang yang apatis terhada berbagai tantangan sosial yang ada dengan dibungkus berbagai dimensi teologis seperti syukur, qanaah, tawakal, dan semacamnya, dibutuhkan suat agresivitas umat Islam dalam mentransformasikan studi Islam sebagai suatu wahana revolusi atas berbagai ketidakadilan sosial yang melanda kehidupan umat Islam. Hal yang sama juga terlihat pada langkah berikutnya seperti dari transfrensi ke inovasi dimana studi Islam diharapkan tidak berlangsung dalam spekrtrum indoktrinitas yang meniscayakan taken for granted atas apa yang disampaikan pada obyek material sekaligus obyek formalnya. Kelima langkah berikutnya yaitu dari teks ke realita, dari kefanaan menuju keabadian, dari teks ke rasio, akal dan alam, serta manusia dan sejarah juga menunjukkan progresivitas berpikir dari Hasan Hanafi dalam mengembangkan studi Islam dalam agenda pertama dari proyek "Tradisi dan Pembaharuan" yang dalam hal ini adalah "sikap kita terhadap tradisi lama"

Adapun dalam kaitannya dengan agenda kedua dari proyek "Tradisi dan Pembaharuan" yang dalam hal ini adalah "sikap kita terhadap tradisi Barat", Hasan Hanafi menegaskan bahwa oksidentalisme bertujuan untuk mengakhiri mitos bahwa Barat adalah refresentasi peradaban manusia sehingga yang benar adalah apa yang benar menurut ukuran Barat dan yang salah adalah apa yang salah menurut Barat. Dalam upaya mewujudkan hal tersebut, pada "sikap kita terhadap tradisi Barat", Hasan Hanafi menunjukkan tiga langkah yang dapat ditempuh yaitu, 1) sumber 
peradaban Eropa, 2) permulaan kesadaran Eropa, 3) serta akhir kesadaran Eropa. ${ }^{24}$ Kehadiran Barat pada kesadaran umat Islam cenderung berlangsung tanpa kritik. Hal ini terjadi karena dalam kesadaran umat Islam, Barat adalah simbol peradaban manusia. Menyikapi hal tersebut, Hasan Hanafi menawarkan perlunya metode kritik dan logika pembuktian atas apa yang berasal dari Barat termasuk ilmu pengetahuan. ${ }^{25}$ Metode kritik dan logika pembuktian yang ditawarkan Hasan Hanafi tersebut bisa menjadi sebuah konstruk epistemologi pengembangan studi Islam dimana berbagai aspek yang dikembangkan harus didudukkan pada suatu ruang yang tidak rigid dalam menerima kritik dan pembuktian. Dalam konteks ini, studi Islam harus didudukkan pada posisi yang sama dengan berbagai studi yang berasal dari Barat melalui pemahaman historis terkait sumber peradaban Eropa, permulaan kesadaran Eropa, serta akhir kesadaran Eropa. Pada dasarnya, masing-masing pihak memiliki dimensi historitas yang diwarnai keunggulan dan kelemahan. Relasi Islam dan Barat harus terbangun dalam bingkai simbiosis mutualisme dengan mengisi satu sama lain. Menyikapi hal tersebut, Muhammad Rusydi menegaskan bahwa studi Islam tidak boleh rigid dalam mengadopsi berbagai literatur keilmuan, termasuk yang berasal dari luar Islam sekalipun, selama literatur keilmuan tersebut memiliki relasi konstruktif dalam pengembangan studi Islam. ${ }^{26}$ Masing-masing pihak harus berdialektika dalam pengembangan ilmu pengetahuan melalui kritik dan pembuktian atas apa yang ditawarkan oleh masingmasing pihak dari berbagai gagasan keilmuan.

${ }^{24}$ Hasan Hanafi, Oksidentalisme: Sikap Kita terhadap Tradisi Barat, h. 3

${ }^{25}$ Hasan Hanafi, Oksidentalisme: Sikap Kita terhadap Tradisi Barat, h. 3

26 Muhammad Rusydi, Akar Teosofis Filsafat Perennial dan Implikasinya pada Pendidikan Islam, (Jurnal Ekspose Vol. 16 No. 2 Tahun 2017), h. 449 
Pada langkah ketiga dari proyek "Tradisi dan Pembaharuan" yang digagasnya yang dalam hal ini adalah "sikap kita terhadap realita", Hasan Hanafi menawarkan tiga langkah yaitu, 1) metodologi, 2) Perjanjian Baru, 3) serta Perjanjian Lama. 27 Semua langkah tersebut mengarah pada suatu konstruk epistemologi pengembangan studi Islam yang memiliki pemahaman terkait realita yang melingkupi pengembangan studi Islam itu sendiri. Pengembangan studi Islam harus memperhatikan berbagai aspek eksternal sebagai tempat penjabaran praktis dari studi Islam melalui metode kritik dan logika pembuktian yang masif.

\section{PENUTUP}

Oksidentalisme Hasan Hanafi merupakan suatu gerakan intelektual yang mencoba mengukuhkan posisi studi Islam sebagai mitra sejajar dengan berbagai studi yang dikembangkan oleh Barat dimana masing-masing pihak harus saling terbuka untuk menerima kritik dan pembuktian atas apa yang dikemukaka dari ilmu pengetahuan. Konstruk epistemologi pengembangan studi Islam bisa mengambil pijakan epistemologis dari oksidentalisme Hasan Hanafi tersebut. Studi Islam yang tidak boleh terpasung pada konstruk epistemologi Barat dan mengacu pada identitasnya sendiri seperti bersandar pada kekuatan spiritual, adanya hubungan yang harmonis antara wahyu dan akal, interdepensi akal dengan intuisi, berorientasi teosentris, dan terikat nilai merupakan suatu konsep ideal dari studi Islam. Hal ini sangat memungkinkan untuk dicapai melalui tiga agenda terstruktur berupa sikap kita terhadap tradisi lama, sikap kita terhadap tradisi Barat, serta sikap kita terhadap realita dengan langkah-langkah dari masing-masing

${ }^{27}$ Hasan Hanafi, Oksidentalisme: Sikap Kita terhadap Tradisi Barat, h. 3 
72 Rausyan Fikr, Vol. 17 No. 1 Januari 2021: 51 - 73.

agenda sehingga pada gilirannya dapat mewarnai konstruk epistemologi pengembangan studi Islam ke depannya.

\section{DAFTAR PUSTAKA}

Abdullah, M. Amin, Islamic Studies di Perguruan Tinggi: Pendekatan Integratif-Interkonektif, Yogyakarta: Pustaka Pelajar, 2006.

Adib, Mohammad, Filsafat Ilmu: Ontologi, Epistemologi, Aksiologi, dan Logika Ilmu Pengetahuan, Yogyakarta: Pustaka Pelajar, 2010.

Arifin, Muhammad Patri, "Hermeneutika Fenomenologis Hasan Hanafi", Rausyan Fikr: Jurnal Studi Ilmu Ushuluddin dan Filsafat, Vol. 13 No.1, 2017, 1-26.

Ernst, Carl W. dan Richard C. Martin, Introduction: Toward a Post-Orientalist Approach, Columbia : University of South Carolina Press, 2010.

Esposito, John L., The Oxford Encyklopedia of the Modern Islamic World, New York: Oxford University Press, 1995.

Falah, Riza Zahriyal dan Irzum Farihah, Pemikiran Teologi Hassan Hanafi, (Jurnal Fikrah: Jurnal Ilmu Aqidah dan Studi Keagamaan Vol. 3 No. 1 Tahun 2015.

Hanafi, Hasan, Dirasat Falsafiyah, Kairo: Maktabah al-Misriyah, tt.

Hanafi, Hasan, Oksidentalisme: Sikap Kita terhadap Tradisi Barat, Terj. M. Najib Buchori, Jakarta: Paramadina, 2000.

Ismail, Faisal, Kontribusi Islam terhadap Eropa pada Abad Pertengahan, https://rumahkitab.com/kontribusi-islamterhadap-eropa-pada-abad-pertengahan// (15 April 2020) 
Kasdi, Abdurrahman dan Umma Farida, Oksidentalisme sebagai Pilar Pembaharuan: Telaah terhadap Pemikiran Hasan Hanafi, Jurnal Fikrah Vol. 1 No. 2 Tahun 2013.

Lenczowski, George, Timur Tengah di Tengah Kancah Dunia, terj. Asgar Bixby, Bandung: Sinar Baru, 1992.

Lukes, Steven, Emile Durkheim: His Life and Work, London: Pinguin Book, 1992.

Madjid, Nurcholis, Kaki Langit Peradaban Islam, Jakarta: Paramadina, 1997.

Nata, Yolies Yongki, Oksidentalisme, JAU: Jurnal Penelitian dan Pemikiran Islam Vol. 2 No.1 Tahun 2015.

Nurhakim, Moh., Islam, Tradisi \& Reformasi: "Pragmatism" Agama dalam Pemikiran Hasan Hanafi, Yogyakarta: Bayumedia Publishing dan UMM Press, 2003.

Qomar, Mujamil, Epistemologi Pendidikan Islam: Dari Metode Rasional Hingga Metode Kritik, Jakarta: Penerbit Erlangga, 2005.

Rusydi, M., Dinamika Studi Islam di Barat, Jurnal Studia Insania Vol. 4 No. 1 Tahun 2016.

Rusydi, Muhammad, Akar Teosofis Filsafat Perennial dan Implikasinya pada Pendidikan Islam, Jurnal Ekspose Vol. 16 No. 2 Tahun 2017.

Sadat, Anwar, Oksidentalisme: Menuju Integrasi Epistemologi Studi Islam, Jurnal Tajdid: Jurnal Pemikiran Keislaman dan Kemanusiaan Vol. 1 No.1 Tahun 2017.

Sholeh, A. Khudori, Filsafat Islam, Sleman: Ar-Ruzz Media, 2014. 